Article

\title{
Environmental, Social and Governance (ESG) and Investment Decision in Bangladesh
}

\author{
Sayema Sultana *(D), Norhayah Zulkifli and Dalilawati Zainal \\ Department of Accounting, Faculty of Business and Accountancy, University of Malaya, \\ 50603 Kuala Lumpur, Malaysia; norhayah@um.edu.my (N.Z.); dalilawati@um.edu.my (D.Z.) \\ * Correspondence: sayema0712@gmail.com; Tel.: +60-11-33-215-220
}

Received: 26 April 2018; Accepted: 19 May 2018; Published: 1 June 2018

check for updates

\begin{abstract}
As a key facet of sustainable development, environmental, social and governance (ESG) discretion on stock market investment decision is gaining prevalence following the global financial crisis. ESG considers the sustainable return, risk reduction, and accountability aspects of investments. This study is an exploration of the individual stock market investors' preferences for ESG issues and the influence that purpose of investment has on investment decision-making, by testing the investment horizon as a moderator. The theoretical background was taken from the theory of planned behavior (TPB), goal setting theory (GST), and the behavioral asset pricing model (BAPM). The study uses the sequential mix method of research, starting with an interview followed by a survey, which was conducted among individual stock market investors in Bangladesh, using simple random sampling. Structural equation modeling (SEM) analysis was carried out using Warp PLS version 6.0. The key findings of this study delineate the effect of ESG issues and the purpose of investment on investment decision-making. The contribution of the study signifies the moderating role of the investment horizon, which confirms the importance of the long-term horizon as a time and risk diversification factor. The sparse utilization of the United Nations Global Compact (UNGC) (2004) and Thomson Reuters Corporate Responsibility Index (TRCRI) (2013) as measurement scales in this study is mentioned. This study has made practical contributions for managers, investors, and regulators.
\end{abstract}

Keywords: ESG; investment decision; the purpose of investment; investment horizon; stock market; sustainable development

\section{Introduction}

The business world has encountered drastic changes in the last few decades due to the global financial crisis (GFC), which evidenced the inescapable interconnectivity of the world economy. This escalated to the apprehension of companies for unethical behavior, oversight of risk, accountability, and the ability to manage stakeholders strategically. In the process of this mutinous change, stock market investors have become concerned regarding environmental, social and governance (ESG) issues of the companies involved. Such views are gaining prevalence and are regarded as one of the key elements towards the sustainable development of a nation and the world in a broader sense, considering that ESG combines sustainable return and risk reduction, with accountability towards the environment and society. When investing, ESG issues account for diverse non-financial aspects of a firm's performance, for instance the firm's operational impact on the natural environment (e.g., carbon emissions, energy, and water use), society (e.g., fair trade principles, health and safety, product safety, and philanthropy), and corporate governance quality (e.g., corruption and bribery, board independence, and stakeholder protection) [1]. The core belief of ESG investing delineates that the investors, society, and environment can benefit from including ESG information in the investment decision. 
The predecessor of ESG was the United Nations Principles of Responsible Investment (PRI), fabricated in 2006, by which the acceptance of ESG in investment decision became more deeply rooted, however, ESG entered concordance in 2008, with the release of an ESG guide by the Chartered Financial Analyst (CFA) Institute, although it is absurd to say that ESG arrived that year, as certain components of ESG had a previous history [2]. Better financial assessment and decision-making is at the core of ESG evaluation in investment decision-making, thus, it considers sustainable growth rather than rapid unstable growth or artificial growth.

The stock market is an imperative part of the economy and has the key intermediary role of moving funds between surplus units and deficit units. Shareholders are considered the prime stakeholders of a company and their role in influencing the companies' practice is paramount. Sustainable development is a global concept [3] that arose a few decades ago [4] and should be evaluated by all stakeholders [5]. The interest of the financial sector in sustainable development is accelerating at a rapid speed, as the victims of unsustainability include both people and the planet itself [6]. Sustainability is an integration of three foundational facets: environmental, social, and economic [7]. ESG issues are considered the three pillars of sustainability [1], and ESG integration in investment decision is showing increasing growth around the world (US\$10.37 trillion) [8]. Although international efforts were taken in the 1980s to ground sustainability, there is still a gap in the understanding of scientific approaches to sustainability [9]. It is crucial to acknowledge the association between finance and sustainability, due to its influential role in capital markets, together with ecological system improvements and reconciling social equity [10].

The significance of ESG rumination in investment decision has had a mountainous impact on the overall sustainability of the stock market, the country, as well as the world economy and society, and ecological balance. The reckless behavior of companies may incur large costs related to clean-up costs in the case of major accidents, sustainability costs, resource consumption costs, loss of consumer trust, potential negative impacts on employee health and morale, responsibilities towards local government, and investing stakeholders [11]. Moreover, ESG virtuous companies can gain customer loyalty, corporate reputation, access to capital, cost savings, innovation capacity, human resource management, and risk management [12], and these, in turn, increase the productivity and the payoff achieved in the long run [13]. Besides, ESG issues provide crucial information about financial performance, like price-earnings ratios; these issues have and will continue to affect the evaluation of companies in the future [14]. The global financial crisis (GFC) has shown the significance of good governance practice. Consequences of ESG malpractices and their effect on the environment, society, and financial market can be illustrated from the incidents of the Exxon Valdez oil spill (1989), Nike's sweatshop criticism (2005), Coca-Cola's labor and environmental malpractice (2006), the BP oil spill of 2010, the Rana Plaza collapse of 2013, the BHS corporate governance scandal of 2016, and so forth.

Bangladesh has been ranked 34th as an emerging country by the World Economic Forum (WEF) [15], with a gross domestic product (GDP) growth rate of 6.6\% [16]. Price Waterhouse Coopers (PWC) has predicted that Bangladesh will be the 23rd biggest economy in the world by 2050 [17]. The retail-based stock markets of Bangladesh are the prime movers of its economy, gaining worldwide attention from multinational titans like JP Morgan, Morgan Stanley, Black Rock, and Goldman Sachs [18], and as a consequence of this, net foreign investment in the Dhaka Stock Exchange Limited (DSE) increased 792 percent in 2016 [19]. Despite such a notable development, the nation faces crises pertaining to ESG issues. For instance, the following major ESG issues have been reported: the stock market crash of 2010-2011 affected more than 3.5 million individual investors [20]; Sonali Bank's loan scandal involved US\$460 million in 2012 [21]; the Rana Plaza collapse in 2013 caused the death of 1129 people and injured 2515 others; the Spectrum Sweater Factory collapse in 2005 killed 64 workers [22]; the Tazreen Garments Fire in 2012 killed around 112 workers and left more than 100 badly injured [23]; and the country's Environmental Performance Index (EPI) [24] is ranked 172nd in the world because of its degrading environmental condition that is threatening national sustainability. 
Despite the fact that non-financial criteria, such as ethical, religious, environmental, social, and governance, in investment decision has been the subject of research for a long time [25-27], surprisingly little advancement has been made regarding the effect of the attitudes of individual investors towards ESG issues in terms of their investment decision; this is an important aspect of sustainability. However, studying the individual investors' inclination towards ESG issues is pivotal due to the inter-connectivity of finance and sustainability, and the influential role of the capital market in reconciling social and environmental equity, the development of ecological systems, and the stability of the financial system. A noteworthy starting point to explore sustainable finance is to recognize the ever-changing demands of heterogeneous investors and to understand their preferences regarding ESG-related issues [10,28-31]. Empirical research is encouraged on ESG issues in emerging economies, as the dedication of the shareholders to these issues is intrinsic to sustainable development [32,33], and can be conducted by different market players [1]. Although there have been studies of the utilitarian benefits to investors, there is a need for studies on the societal concerns of investors [30], and the individual weightings given to preferences for ESG criteria [34]. Individual weightings could be established by using quantitative methods to generalize the impacts of these dimensions on finance, investment, and sustainability [10]. There is an obvious distinction between the East and West in terms of philosophies, institutions, and cultural values [35]. Hence, it is recommended that studies be conducted in cultures other than typical Western cultures. Moreover, the purpose of the investment is vital, as specifying the purpose or goals of investment is one of the primary considerations in an investment decision [36].

The contribution of the study signifies the use of the investment horizon as a moderator between ESG issues and the investment decision, and confirms the importance of the long-term horizon on ESG investment decision. The impact of the purpose of investment on investment decision-making is evaluated following the suggestions from an interview conducted at the beginning of the study; this can add value from the cultural context of the ESG and sustainability literature. The impact of the purpose of investment on investment decision has rarely been studied in the previous ESG literature. The measurement scale was adapted from the United Nations Global Compact (UNGC) (2004) [37] and the Thomson Reuters Corporate Responsibility Index (TRCRI) (2013) [38], these sources, together with other relevant literature, contribute to the literature with a unique combination of measuring methods that gauge the preferences of investors on ESG issues with a reliable, valid, and versatile scale, with individual weightings given to the preferences of ESG dimensions. Besides, a combined measurement scale used to measure investment decision has scarcely been used in previous literature. In addition, due to the heterogeneity of the social investors, this study profiles individual investors in an emerging economy where ESG issues have substance. One potential implication of the study is that appropriate communication to different stakeholder groups about the ESG preferences of investors could help in changing their mindsets concerning the particular ESG issues with regard to sustainable development. This study has practical implications for companies who can recognize the demand for ESG from investors, act in a sustainable manner, and generate long-term value. Regulators can also identify the importance of this and form rules and regulations to improve ESG reporting and performance. Additionally, regulators could start initiatives for the introduction of the ESG index in Bangladesh or other countries with similar cultural settings. Investors will in turn benefit from sustainable investment return, ensuring their accountability towards the environment, society, and economic balance. This will sequentially lead to the sustainable development of the nation and the world.

The rest of the article is organized as follows; in Section 2 a literature review of the relevant field and hypotheses are presented; the methodology used for the study is described in Section 3; the results of the study are presented in Section 4; a discussion of the findings of the study is found in Section 5; and the study conclusions are drawn in Section 6.

\section{Literature Review and Hypotheses Development}

An investment decision is an important process that involves selecting a stock from a wide range of options available on the various stock markets. The traditional economic theory assumes that 
people are rational agents and make decision objectively based on their knowledge, experience and expectations and are capable of taking advantage of the opportunities available to them. However, emotional inclination, ingrained thought patterns, and the psychological biases of different human beings - that is, the behavioral paradigm of financial decision-making-describes how investors perceive the world and make investment decision [39-41]. Investment decision was previously followed by an ordinary triangle covering risk, liquidity, and return, however, a growing number of investors nowadays use the phenomenal square, covering liquidity, risk, return and sustainability [42]. Henceforth, the investment decision process of investors is not unique to all investors, but rather is heterogeneous to various investors. Different investors use different strategies in selecting stocks or bonds. One group of investors might only consider the financial outcomes of an investment and make their investment decision accordingly, while another group of investors might consider both the financial outcomes and the ESG issues in their investment decision. The present study explores the ESG investment decision of stock market investors by measuring their willingness to pay a premium price, at the expense of return, and the percentage of portfolio investments in companies with rigorous ESG practices.

Environmental issues bear significance when making an investment decision. Environmental issues include air, water or resource pollution, greenhouse gas (GHG) emissions, climate change, changes to the nitrogen and phosphorus cycles, ocean acidification, changes in land use, waste management, biodiversity loss, stratospheric ozone depletion, renewable energy, energy efficiency pertaining to the quality and operation of the environment, and natural systems [43]. The functioning of the economy and society must consider the environment and climate change due to the back and forth effects of social transformation, economic development, scarcity of natural resources, and population growth $[10,44]$. The impact businesses have on the environment has gradually been given additional importance by a wealth of literature due to the visible, far-reaching impact on biodiversity, the damage to natural resources, and accelerated global warming caused by corporate business. Hence, companies with virtuous environmental practices can give credence to the generation of reasonable and sustainable financial returns, together with fulfilling their environmental accountabilities. Several prior studies have documented the relationship between environmental aspects and investment decision-making process, for example in the USA, Japan, India, France, and Australia. Investors in the USA expressed that the evaluation of environmental issues helps them judge a companies' socially responsible behavior [45]. ESG practice disclosures by certain French firms impacted the investment decision and firm evaluation of private equity investors whose socially irresponsible practices or policies regarding the environment reduced the investment likelihood by $30.8 \%$ [46]. In addition, environmental issues are the most influential element of Indian investors to achieve non-economic investment goals [25]. In contrast, the Brazilian stock market does not reflect the incorporation of environmental issues in investment decision [32]. Irresponsible industrial behaviors contribute to environmental pollution in Bangladesh [47]. With the increasing attention of investors around the globe regarding the impact of environmental issues on investment decision, it is important to examine whether investors in Bangladesh consider environmental issues in their investment decision. This lead to the development of the first hypothesis of this study.

Hypothesis 1 (H1). Environmental issues have a positive influence on the investment decision of the stock market investors of Bangladesh.

Social issues are subjects related to the well-being, rights and interests of people and communities, mainly including workplace health and safety; human rights; slave, child, and bonded labor; labor standards in the supply chain; diversity; freedom of expression and freedom of association; health and access to medicine; employee relations and human capital management; relations with local communities; controversial weapons and consumer protection; and activities in conflict zones [43]. Social issues are one of the dominant parts of the ESG under consideration by Australian 
superannuation fund investors [48], the community-employee relationship and human rights are considered by investors in their investment decision [49]. Additionally, social issues are rated more highly than other issues like environmental and governance issues by the Australian investors [50]. In contrast, social issues are not evaluated by stock market investors in Brazil [32]. Globally, there is an accelerating trend among investors towards contemplating the social issues of the companies they invest in. Therefore, to explore whether investors in Bangladesh consider the social issues of companies in their investment decision, we constructed our second hypothesis.

Hypothesis 2 (H2). Social issues have a positive influence on the investment decision of the stock market investors of Bangladesh.

The economic rationality of the investors has a dominant correlation with the governance practice of the companies. Profitability is essential to resource allocation, sustainable business, and the economic system [51]. Companies with efficient governance practices are more likely to have responsible social and environmental practices. Governance issues relate to the governance of firms and other investee entities, and include board size, structure, diversity, skills, independence, internal controls and risk management, executive pay, disclosure of information, business ethics, shareholder rights, stakeholder interaction, relationship between a company's management staff and other stakeholders, bribery, and corruption [43]. Investors have special consideration for social issues as long as they are also aligned with healthy financial returns, indicating their preference for the governance issues of the company $[49,50]$. Corporate governance is preferred by $64 \%$ of the respondents when making their investment decision in Australia [48], whereas governance issues are not considered by stock market investors in Brazil [32]. The GFC has increased the demand for better governance from different stakeholder groups. However, whether stock market investors are considering corporate governance issues is unknown when considering a country where investors have recently faced a stock market crash and corporate governance scandals. In light of the accelerating global awareness of governance issues in the investment decision, largely for the indemnity of investment, and the recent corporate governance scandals in Bangladesh, the third hypothesis of this study was constructed.

Hypothesis 3 (H3). Governance issues have a positive influence on the investment decision of the stock market investors of Bangladesh.

The purpose of investment has significance regarding the investment decision-making process. The investment objectives or purposes of individual investors are crucial to understanding the overall investment decision and investment performance [52]. Investors usually start their investment decision by allocating their wealth amongst investment purposes or goals [53]. The identification and determination of the purposes of investment can play a dominant role in explaining the investment decision and how it relates to ESG issues; according to the findings of an interview conducted among six academics, institutional, and professional investors at the beginning of this study. The findings of the interview indicated that investors who invested in stocks for saving purposes might be more interested in ESG investments when compared to investors whose purpose of investment was to earn regular income from stock market investment. Previous studies $[54,55]$ have used the purpose of investment merely to describe the investors' demographic characteristics, therefore, this study used this variable and explored its impact on the investment decision relating to ESG issues, and thus, the fourth hypothesis was proposed.

Hypothesis 4 (H4). Savings purpose has a positive influence on the investment decision of the stock market investors of Bangladesh.

The investment horizon, which refers to short-term, medium-term, or long-term investment strategies, is crucial to ESG investment decision. The emphasis regarding the investment horizon, 
ESG investment and the involvement of the financial sector should be given special attention [10]. Sustainable investment return is associated with long-term strategies and therefore the investment horizon can play a dominant role in the ESG investment decision and value creation. As the primary aim of a company is long-term value creation and wealth maximization [56], the value-creation approach of sustainability is related to risk reduction [57]. If the return is good, the long-term investors are ready to accept a short-term fall in their investment; no significant differences in the investment horizons of socially responsible and non-socially responsible investors were found among Australian investors [50]. On the contrary, a short-term investment horizon is a major obstacle for socially responsible investment by Swedish institutional investors [58]. However, the extent to which an investment strategy supports a long-term paradigm is influenced by the scope and sophistication of the individual approach and concept [51]. In addition, the investment horizon may impact the riskiness of the investment. The importance of the time horizon to the investors in their asset allocation remains open for discussion [59]. The investment horizon is related to time diversification [60], which is associated with risk diversification, and understanding the role of the investment horizon in terms of ESG issues and the investment decision is paramount. Additionally, to obtain a more congruent picture of sustainable investment and corporate sustainability it is crucial to test different moderating and mediating variables [61,62]. Therefore, to examine the moderation of the investment horizon between ESG issues and the investors' investment decision in Bangladesh, a fifth hypothesis was developed.

Hypothesis 5 (H5). The investment horizon moderates the relationship between ESG issues and the investment decision of the stock market investors of Bangladesh. In the light of this hypothesis, three other related hypotheses were formed.

a The influence of the environmental issues on investment decision is stronger when investors have long-term investment horizon.

$b \quad$ The influence of social issues on investment decision is stronger when investors have long-term investment horizon.

c The influence of governance issues on investment decision is stronger when investors have long-term investment horizon.

Figure 1 exhibits the research framework of this study.

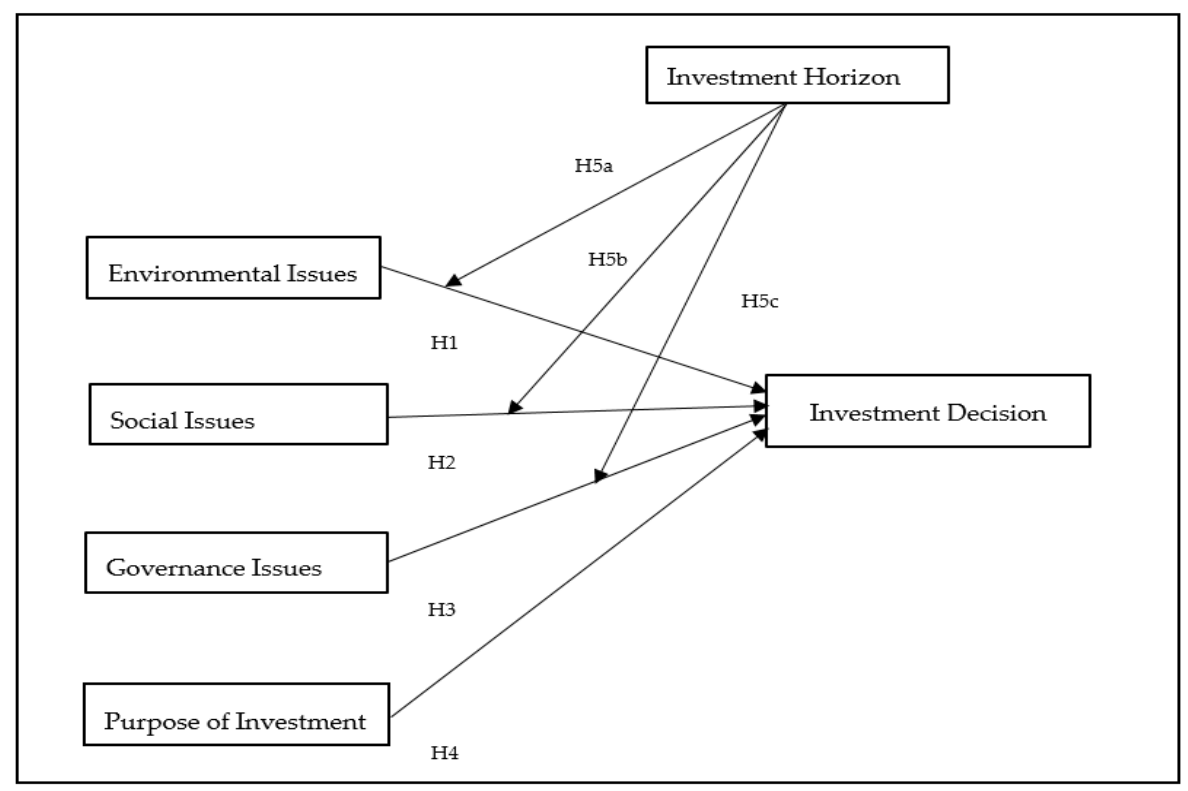

Figure 1. Research framework of the present study. 


\section{Methodology}

\subsection{Theoretical Underpinning}

The theoretical underpinning of this study is based on the theory of planned behavior (TPB), goal setting theory (GST), and behavioral asset pricing model (BAPM). TPB explains that human 'intention' depends on 'attitudes toward behavior', 'subjective norms', and 'perceived behavioral control'; 'intention' ultimately leads to 'actual behavior' [63]. However, the present study uses only one component, 'attitude', to predict 'intention' based on the objectives of the study. The partial adoption of the TPB in other research papers can also be found $[64,65]$. The TPB is operationalized by exploring the 'attitudes' of stock market investors regarding ESG issues, and thus focusing on the 'intention' towards ESG investing with the consideration of investment decision. 'Attitude' toward a behavior is defined as a total set of obtainable behavioral beliefs [66], and an individual's readiness to perform a behavior is defined as an 'intention' [67]. Considering that attitude, among other psychological constructs, can predict and explain social behavior concisely [67], and investors' attitudes towards different investment criteria have significance when making investment decision [68,69], the 'attitude' and 'intention' components of TPB are considered. Additionally, previous literature [70,71] reported the strong impact of attitude on intention among investors. To explain the relationship between the purpose of investment and the investment decision, GST was used, which denotes that goals and intentions are related to behavior regardless of incentive conditions [72]. Besides, the theoretical framework was improved by adding the investment horizon as a moderator in ascertaining the effect on the investment decision of the ESG aspects drawn from the BAPM explanation. In BAPM, the utilitarian, expressive and emotional benefits are included, and it states that the value of the investment or expected return of the stock depends on risks, social responsibility, liquidity, thrill, prestige, misleading emotions, cognitive errors, and so forth [73]. The classical theory professes that as the investment horizon increases, the risk of the investment decreases, at which time diversification is possible $[60,74]$. Therefore, risk and investment horizon are intercorrelated elements of the investment decision. Moreover, the investment horizon is related to the predictive return and riskiness of the portfolio investments [75,76], which is significant in stockholding [77]. The investment horizon may impact the riskiness of the investment, however, the importance of the time horizon of the investors in their asset allocation remains open for discussion [59]. ESG investment claims to be related to risk reduction, due to the virtuous ESG practices of companies and the long-term value creation and wealth maximization for the stakeholders $[2,78]$. However, the moderating role of the investment horizon bears significance regarding the understanding of the roles of risk diversification and social responsibility in the value of the stocks and investment decision, as highlighted in BAPM.

\subsection{Method}

This study uses the sequential mix research method, which starts with an interview followed by a questionnaire survey. In this approach, the researcher conducts an initial phase of qualitative data collection and analysis, then uses quantitative data collection in the analysis approach, which is beneficial to exploring a phenomenon during the development and testing of a new instrument [79]. At first, a semi-structured interview was conducted with three academicians and three professional and institutional investors to learn their inclusive views on the ESG practices of companies operating in Bangladesh, as well as the considerations of the current stock market investors on ESG issues. Secondly, a questionnaire survey was conducted on individual stock market investors of the Dhaka Stock Exchange Limited (DSE) and Chittagong Stock Exchange Limited (CSE), with simple random sampling used to collect final data, as this was the main part of the research pertaining to the objectives. Therefore, the present study used the positivist paradigm, as this mode of accounting research seeks to uncover law-like regularities that are testable by empirical datasets [80]. For the pilot study, 65 questionnaires were distributed among individual stock market investors and the academics from the accounting and finance departments of two eminent universities in Bangladesh. The 34 responses were collected to 
check reliability and face validity and modifications to the survey instrument were made accordingly. Interview suggestions were incorporated into the questionnaire and objective of the study. In total, 768 questionnaires were distributed for a sample size of 384 [81,82]. However, the minimum sample size for the study was determined using Warp PLS (Version 6.0) with a power of 0.80; the inverse square root method was used to calculate the minimum sample size (160) and the Gamma-exponential method was used to determine the sample size of 146. Finally, 343 useable responses, with a response rate of $44.66 \%$, were analyzed. Subsequently, this study used scientific methods to test the hypotheses, the methods were quantitative in manner and helped us to reach a rational explanation of the problem raised in the study. To analyze the quantitative data, we used the Statistical Package for Social Science (SPSS) version 22.0 software and structural equation modeling (SEM) in conjunction with Warp-PLS version 6.0, which is a definitive software for SEM to present partial least squares (PLS) algorithms, as well as factor-based PLS algorithms that account for measurement error and produce estimates of true composites together with factors $[83,84]$.

\subsection{Research Instrument}

A comprehensive research instrument was adapted for this study, as an improvement to ESG measurement scales is required to fulfill the needs of the long-term paradigm [51]. It is encouraged to add both a belief aspect-cognitive process to explain an object-as well as an affective aspect-liking or disliking an object-to measure attitudes [85]. Therefore, the scales were adapted to measure three homogeneous independent variables; environmental issues (13 items); social issues (14 items), and governance issues (15 items); we accumulated both the aspects drawing support from the dimensions of ESG, adapted from the internationally recognized United Nations Global Compact (UNGC) (2004) [37] and the Thomson Reuters Corporate Responsibility Index (TRCRI) (2013) [38], as well as other relevant literature $[26,48,86,87]$. The seven points of the Likert scale, ranging from 'strongly disagree' to 'strongly agree', were used with two negative items for each independent variable to protect against acquiescence and random responding [88]. Purpose of investment was measured using a nominal scale from previous literature [55], however, an expert panel was used to divide the purposes of investment between the savings purpose and the regular income purpose. This variable was analyzed as a dummy variable during data analysis. To measure the dependent variable and the investment decision of the investors, we used three-item ordinal scales, measuring the percentage of ESG investment in the portfolio, the willingness to pay a premium price, and the sacrifice of return for companies practicing ESG $[26,50,89,90]$. The moderating variable, investment horizon, was measured with a one-item ordinal scale [26].

\section{Results}

This section provides the results and analysis of the study. Table 1 illustrates the demographic profile of the respondents.

Table 1. The demographic profile of the respondents.

\begin{tabular}{lll}
\hline Items & Characteristics & Response (\%) \\
\hline Gender & Male & 91.50 \\
& Female & 8.50 \\
\hline \multirow{2}{*}{ Age } & Less or equal 20 years & 0.90 \\
& 21 to 30 years & 32.90 \\
& 31 to 40 years & 40.50 \\
& 41 to 50 years & 19.80 \\
& Above 50 years & 6.70 \\
\hline
\end{tabular}


Table 1. Cont.

\begin{tabular}{lll}
\hline Items & Characteristics & Response (\%) \\
\hline Religion & Islam & 87.20 \\
& Hinduism & 10.50 \\
& Buddhism & 2.00 \\
& Christianity & 0.30 \\
\hline Education & Below Secondary School Certificate (S.S.C.) & 0.30 \\
& Secondary School Certificate (S.S.C.) & 20.40 \\
& Higher Secondary School Certificate (H.S.C.) & 28.60 \\
& Bachelor's degree & 21.00 \\
& Master's degree & 22.70 \\
& Professional Degree & 7.00 \\
\hline Experience & Less than 5 years & 39.40 \\
& 5 to 10 years & 41.40 \\
& More than 10 years & 19.20 \\
\hline Purpose of Investment & Regular income & 64.70 \\
& Savings & 35.30 \\
\hline Investment Horizon & Short-Term & 71.40 \\
& Long-Term & 28.60 \\
\hline Income Level & Less or equal *BDT 500,000 & 44.00 \\
& BDT 500,001 to 1,000,000 & 25.40 \\
& BDT 1,000,001 to 1,500,000 & 16.30 \\
& BDT 1,500,001 to 2,000,000 & 8.70 \\
& Above BDT 2,000,000 & 5.50 \\
\hline & BDT 500,000 or less & 25.10 \\
& BDT 500,001 to 1,500,000 & 21.90 \\
& BDT 1,500,001 to 2,500,000 & 19.20 \\
& BDT 2,500,001 to 3,500,000 & 18.70 \\
& BDT 3,500,001 to 4,500,000 & 9.00 \\
& Above BDT 4,500,000 & 6.10 \\
\hline & & \\
& & \\
& & \\
& &
\end{tabular}

${ }^{*}$ BDT = Bangladeshi Taka; 1 USD = BDT 82.95 as on 15 March 2018.

\subsection{Structural Equation Modeling (SEM)}

Structural equation modeling (SEM) depicted the relationships between the constructs and their corresponding indicator variables, whereas the latent variable relationship was described by the structural model [91].

\subsubsection{Measurement Model Assessment}

To evaluate the reflective measurement model, the reliability tests-Cronbach's alpha and composite reliability—and the validity tests—convergent validity and discriminant validity—were conducted [91]; the results of reliability, discriminant validity and multicollinearity tests are shown in Table 2.

Table 2. Reliability, validity and multicollinearity test results.

\begin{tabular}{lcccc}
\hline & Reliability Tests & $\begin{array}{c}\text { Discriminant } \\
\text { Validity Test }\end{array}$ & Multicollinearity Test \\
\hline \multicolumn{1}{c}{ Constructs } & Composite Reliability (CR) & Cronbach's Alpha & $\begin{array}{c}\text { Average Variance } \\
\text { Extracted (AVE) }\end{array}$ & Full Collinearity VIF \\
\hline Environmental Issues (E) & 0.929 & 0.917 & 0.502 & 2.151 \\
Social Issues (S) & 0.935 & 0.925 & 0.506 & 2.733 \\
Governance Issues (G) & 0.939 & 0.930 & 0.505 & 3.060 \\
Investment Decision (InDec) & 0.914 & 0.859 & 0.781 & 4.556 \\
\hline
\end{tabular}




\subsubsection{Reliability Tests}

Composite reliability (CR), the criterion showing indicator reliability, should be greater than 0.8 [92], and the Cronbach's alpha value should be above 0.80 [93]. The composite reliability (CR) and Cronbach's alpha of all scales in this study were above 0.80 , which indicated that the scales were sufficiently reliable to ensure construct reliability (Table 2).

\subsubsection{Validity Tests}

Convergent validity of the constructs was assessed with the factor loadings. The factor loadings of most of the items were above the minimum acceptance range of 0.70 [94]. Items E1, E11, S1, and S11 had factor loadings below 0.70 . However, items with weak factor loading can be retained in some cases as a benefaction to content validity [91]. Therefore, none of the items were deleted from the constructs. To confirm the discriminant validity of the measurement model, the average variance extracted (AVE) should be greater than 0.50 [91]. Table 2 shows, the AVE of all the constructs are above 0.50 confirming the discriminant validity of the present study's measurement model. Additionally, Table 3 illustrates the correlations of the latent variable with the square roots of the AVE, shown diagonally. In this study, the square roots of the AVE are greater than any other correlations among the latent variables that show good discriminant validity [93].

Table 3. Correlations among latent variables with square roots of the average variance extracted (AVE) shown diagonally.

\begin{tabular}{lcccc}
\hline \multicolumn{1}{c}{ Constructs } & $\begin{array}{c}\text { Environmental } \\
\text { Issues }\end{array}$ & Social Issues & $\begin{array}{c}\text { Governance } \\
\text { Issues }\end{array}$ & $\begin{array}{c}\text { Investment } \\
\text { Decision }\end{array}$ \\
\hline Environmental Issues & $(0.708)$ & 0.671 & 0.601 & 0.616 \\
Social Issues & 0.671 & $(0.711)$ & 0.697 & 0.653 \\
Governance Issues & 0.601 & 0.697 & $(0.711)$ & 0.677 \\
Investment Decision & 0.616 & 0.653 & 0.677 & $(0.884)$ \\
\hline
\end{tabular}

\subsection{Multicollinearity Test}

It is of great importance to check the multicollinearity in the model to ensure the quality of the measurement scale, otherwise the independent variables may cause inflation of the effect sizes [95]. Warp PLS 6.0 calculates the vertical and lateral collinearity using the test of full variance inflation factor (VIF) [84]. Moreover, full collinearity VIF can be used to check for common method bias and considered superior to the exploratory factor analysis [96]. It is recommended that the VIF score should be less than 5, and more conservatively less than 3.3 [94]. Table 2 summarizes the full collinearity VIF values for all independent variables, which were less than 3.3 for all constructs, confirming that there was no multicollinearity in the model. Though the dependent variable had a VIF value of 4.556 , it is still within the acceptable threshold [84].

\subsubsection{Structural Model Assessment}

The aim of the structural model is to investigate the model fit of the hypothesized research model [97]. The relationships of the constructs defined in the theoretical model were assessed through the coefficient of determination $\left(R^{2}\right)$, path coefficient $(\beta)$, effect size $\left(f^{2}\right)$, and predictive relevance $\left(Q^{2}\right)$. The path coefficient $(\beta)$ describes the hypothesized relationship between the variables, the $p$-value assesses the significance level, the coefficient of determination $\left(R^{2}\right)$ is the measure of the research model's predictive power [91], and the Q-squared coefficient (Stone-Geisser Q-squared coefficients, $\mathrm{Q}^{2}$ ) is a nonparametric measure used to assess the predictivity of the model [98]. In addition, the missing data imputation algorithm used in the study was the arithmetic mean imputation, the outer model analysis algorithm was PLS regression and the resampling method was Stable3. 
Figure 2 depicts the structural model of the study and Table 4 lists the structural model parameters with an indication of the test results for the hypotheses. The path coefficient $(\beta)$ between environmental issues (E) and the investment decision (InDec), was found to be positive and significant ( $\beta=0.15$, $p<0.01)$ with a small to moderate [99] effect size $\left(\mathrm{f}^{2}=0.09\right)$. This confirms H1, meaning that companies' environmental issues (E) have a notable effect on the investors' investment decision. In addition, the path coefficient $(\beta)$ between social issues (S) and the investment decision (InDec), indicated that the relationship was positive and significant $(\beta=0.15, p<0.01)$, with a small to moderate [99] effect size $\left(\mathrm{f}^{2}=0.10\right)$. This confirmed $\mathrm{H} 2$, regarding interpreting the positive influence of social issues $(\mathrm{S})$ on the investors' investment decision. Moreover, the path coefficient $(\beta)$ between governance issues $(\mathrm{G})$, and the investment decision (InDec) was positive and significant $(\beta=0.25, p<0.01$ ), with a moderate to large effect size [99] $\left(\mathrm{f}^{2}=0.17\right)$. This affirmed $\mathrm{H} 3$, meaning that when the preference for governance issues $(\mathrm{G})$ was high, the effect of these issues on the investment decision was also high. Furthermore, among ESG issues, governance issues $(\mathrm{G})$ showed a stronger effect on the investment decision. The impact of the purpose of investment on the investment decision was found to be significant $(\beta=0.13, p<0.01)$, which supports $\mathrm{H} 4$, and indicates that investors whose investment purpose was savings showed greater preference towards ESG investment decision. As a moderator, the investment horizon of an investor played an important and positive role in the relationship between ESG issues and the investment decision, suggesting that having a long-term investment horizon tends to affect this relationship, supporting $\mathrm{H} 5 \mathrm{a}, \mathrm{H} 5 \mathrm{~b}$, and $\mathrm{H} 5 \mathrm{c}$. The relationship between environmental issues $(\mathrm{E})$ and the investment decision $(\mathrm{InDec})$ was moderated through investment horizon (IH) significantly $(\beta=0.11, p<0.05)$ with a small effect size $\left(\mathrm{f}^{2}=0.06\right)$. Interestingly, a similar significant moderating effect of investment horizon (IH) was found $\left(\beta=0.10, p<0.05, \mathrm{f}^{2}=0.06\right)$ for the relationship between social issues (S) and investment decision (InDec), and for governance issues $(\mathrm{G})$ and the investment decision (InDec). The coefficient of determination $\left(\mathrm{R}^{2}\right)$ of the model was 0.61 and the Stone-Geisser Q-squared coefficients $\left(Q^{2}\right)$ were 0.62 , which means that the predictive power of the study model is moderate [95].

Age, education level, income level, and the investment amount of the investors were controlled for this study, and it was found that the age $(p=0.189)$ and educational level $(p=0.474)$ of the investors did not have any impact on their investment decision. In contrast, the income level $(\beta=0.12, p=0.01)$ and investment amount $(\beta=0.16, p=0.001$ ) of the investors significantly contributed to the investment decision of investors. Moreover, the predictive power or $\mathrm{R}^{2}$ of the model with controlled variables was 0.65 , meaning that the control of the variables could explain an additional $4 \%$ predictivity of the model.

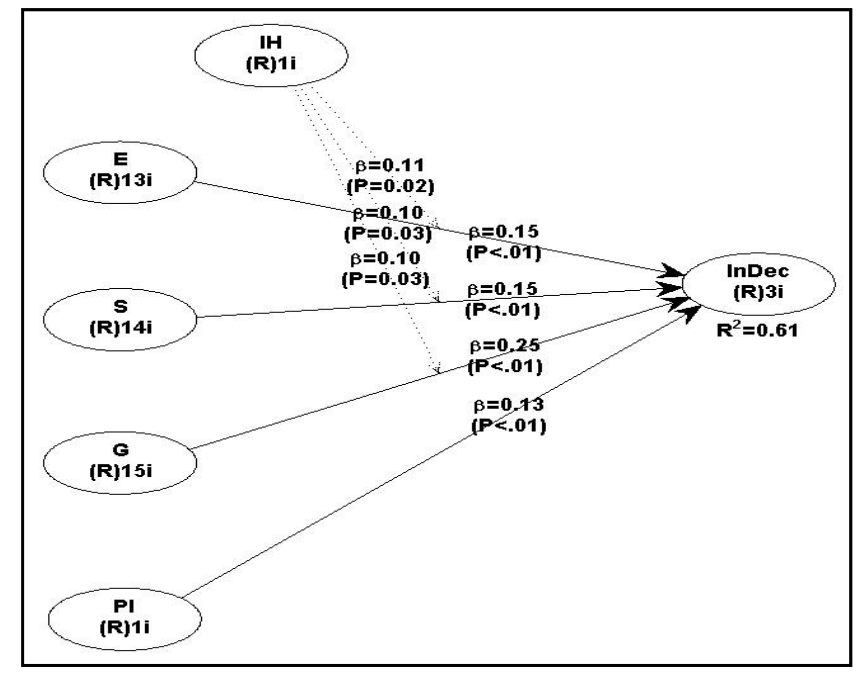

Figure 2. Structural model of the study. 
Table 4. Structural model parameters and hypotheses testing.

\begin{tabular}{|c|c|c|c|c|}
\hline Paths & $\beta$ & $p$-Values & $\mathbf{f}^{2}$ & Hypotheses \\
\hline E->InDec & 0.15 & $0.002 * *$ & 0.09 & H1: Supported \\
\hline S->InDec & 0.15 & $0.003^{* *}$ & 0.10 & H2: Supported \\
\hline G->InDec & 0.25 & $0.001 * *$ & 0.17 & H3: Supported \\
\hline PI->InDec & 0.13 & $0.007^{* *}$ & 0.08 & H4: Supported \\
\hline \multicolumn{5}{|c|}{ Moderating Effect: Investment Horizon } \\
\hline $\mathrm{E}->\mathrm{InDec}$ & 0.11 & $0.02 *$ & 0.06 & H5a: Supported \\
\hline S->InDec & 0.10 & $0.03 *$ & 0.06 & H5b: Supported \\
\hline G->InDec & 0.10 & $0.03 *$ & 0.06 & H5c: Supported \\
\hline \multicolumn{5}{|c|}{ The coefficient of determination $\left(\mathrm{R}^{2}\right)=0.61$} \\
\hline
\end{tabular}

\subsubsection{Model Fit Indices}

Warp PLS 6.0 uses a divergent set of measures to check the model fit in order to observe the required fit of the PLS-SEM model [84]. The model fit and quality indices of the present study model are listed below in Table 5, which indicates the acceptability of the model while considering the listed thresholds.

Table 5. The model fit and quality indices of the present study model.

\begin{tabular}{lllc}
\hline \multicolumn{1}{c}{ Measures } & \multicolumn{1}{c}{ Model Fit Indices } & \multicolumn{1}{c}{ Recommendation } & References \\
\hline The Average path coefficient (APC) & $0.142, p<0.01$ & Significant at the $p<0.05$ level & {$[100]$} \\
Average R-squared (ARS) & $0.613, p<0.001$ & Significant at the $p<0.05$ level & {$[100]$} \\
Average Adjusted R-squared (AARS) & $0.605, p<0.001$ & Significant at the $p<0.05$ level & {$[100]$} \\
Average block VIF (AVIF) & 2.460 & Acceptable if $\leq 5$, ideally $\leq 3.3$ & {$[84]$} \\
Average full collinearity VIF (AFVIF) & 3.016 & Acceptable if $\leq 5$, ideally $\leq 3.3$ & {$[83]$} \\
Tenenhaus GoF (GoF) & 0.622 & Small $\geq 0.1$, Medium $\geq 0.25$, & {$[101]$} \\
Simpson's paradox ratio (SPR) & 1.000 & Large $\geq 0.36$ & {$[84]$} \\
$\begin{array}{l}\text { R-squared contribution ratio (RSCR) } \\
\text { Statistical suppression ratio (SSR) }\end{array}$ & 1.000 & Acceptable if $\geq 0.7$, ideally $=1$ & {$[84]$} \\
$\begin{array}{l}\text { Nonlinear bivariate causality } \\
\text { direction ratio (NLBCDR) }\end{array}$ & 1.000 & Acceptable if $\geq 0.9$, ideally $=1$ & {$[84]$} \\
\hline
\end{tabular}

Hence, the model fit indices confirm the acceptability of the model of the present study.

\section{Discussion}

This study provides initial empirical evidence of the extent of the individual stock market investors' inclination towards ESG investment in one of the emerging economies of the world. The present study elaborates on the current ESG and sustainability literature by establishing that stock market investors in Bangladesh show an equal preference for environmental issues and social issues. However, strongest greatest preference was for governance issues. Of the environmental issues, generating contemporary market opportunities through advanced environmental processes and technologies was generally the most preferred by the investors, followed by proper waste management of harmful wastes from production processes, producing environment-friendly and durable products, and reducing harmful gases (carbon dioxide and chlorofluorocarbons) from the production process. These findings show the eagerness of the investors to invest in environmentally friendly production processes and the anti-pollution activities of firms, through which the sustainable development of the society, country, and the world is possible. Investors' preferences for environmental issues is likely a cumulative effect of awareness of industrial pollution, climate change issues, environmental degradation, risk reduction, sustainable investment return, and so forth. Additionally, investors firmly 
believe that a company with standard environmental practices will perform better in the long run and vice versa. They have also shown their interest in considering the environmental practices in their investment decision, and agreed that non-environmentally-friendly firms were risky investments.

With regard to social issues, the present study ascertains the preference of investors for the workplace safety and health of employees and workers, followed by equal preference given to developing employee skills, competencies, employability, and careers by arranging training and education, thus increasing the employees' productivity and loyalty by advancing an effectual life-work balance, a family-friendly environment, and equal opportunities irrespective of age, gender, ethnicity, or religion. Additionally, preferences were found regarding respecting elementary human rights conventions (not using children, forced or compulsory labor, etc.), producing standard goods and services that consider the customers' health and safety, and providing accurate product information and labeling. Most of the inclination towards workers' and employees' safety relates to the recent incidents of the Rana Plaza collapse and fire accidents in the garments industries. Furthermore, investors vigorously believe that, together with financial issues, if they consider the social issues of the companies they invest in it will bring a higher return on their investment. This belief links to expectations that social issues will secure healthy investment returns. Besides, investors' interest in investing in socially virtuous firms is notable. Additionally, the research justifies the bounded rationality towards the economic entities of the investors, where the investors perceive benefit from an investment to be the sum of the social, economic, and psychological benefits [102], whereas most of the theories of finance consider investors as rational economic entities who prefer only economic gain from investment. However, ESG is an investment concept where there is cross-over between traditional finance theories and behavioral finance theories, because ESG issues have an impact on the long-term investment return. Therefore, the consideration of environmental and social issues in investment decision can be due to economic preferences, social and environmental concerns, or both. In contrast, governance considerations in the investment decision are purely related to the rationality of the investors, which is backed by pure financial theories.

This study reveals that investors prioritize the setting up of an effective board with allocated duties and responsibilities for all corporate governance issues, followed by the adherence to financial reporting requirements, and the independence of auditors. Again, the independence and accountability of the board of directors and audit committee structure, and its functions are considered to be important factors among corporate governance issues. Corporate governance inclinations have relevance to the corporate governance scandals in Bangladesh as well as around the world in recent years. In addition, investors strongly believe that investment in a company that has been penalized by the relevant regulatory authorities for corruption or other governance malpractices is risky. Moreover, investors relate standard corporate governance practices with better, more sustainable performance and financial returns in the long run. In Bangladesh, individual stock market investors showed their inclination to pay premium prices for the shares in ESG practicing companies. Investors also tended to reward firms with acceptable ESG practices by preferring to pay a premium price for the company's shares. At the same time, this can be related to one of the strategies to secure investment return, together with paying more for the reputed firms as a goodwill gesture.

The influence of the savings purpose of investment was found to be a significant factor in investment decision, and is associated with the concept that investors who are saving for children/grandchildren, future retirement benefits, the purchase of property, diversification of investments, or investment in mutual funds consider ESG investments to be more attractive than for regular income purposes, such as enhancing their current lifestyle, income for basic needs, extra income, higher rate of return than other investments. This may be relevant to the reliability of ESG investments for future benefits.

Additionally, the investment horizon proved to be successful in moderating the relationship between ESG issues and the investment decision. This signifies that the investors had a better understanding of the fact that in order to gain a sustainable return and competitive advantage from 
ESG investments, a longer time horizon is one of the predominant factors to be focused on and integrated. Investors maintained that ESG issues require time to be exercised, implemented, and for significant returns on investment to be realized. This study found that investors with a long-term horizon are more inclined to participate in ESG investments.

The use of TPB, GST, and BAPM can enrich the ESG literature by aiding the understanding of investors' attitudes and preferences from the divergent perspectives of psychology and motivational literature and behavioral finance literature. The utilization of TPB and GST confirms the impact of human attitudes and goals in predicting intention. In the light of BAPM, the moderating role of the investment horizon asserted the importance of a long-term horizon as a time and risk diversification factor in the evaluation of ESG investments from the investors' perspective.

The findings related to the control variables used in this study identified other possible factors influencing the ESG investment decision. The demographic characteristics of the social investors are an important factor for understanding their attitudes and behavior [33]. In this study, age was a control variable, but not a significant one; this finding supports the previous literature $[27,90]$. In addition, the education level of investors had an insignificant effect on the investment decision, which contradicts the previous literature [26,27], which indicated that an educated investor would be more concerned about ethical, environmental, social, or governance issues. A possible explanation for these findings might be the presence of a comparatively well-educated investor pole in the stock markets of Bangladesh. For instance, most of the respondents $(72.30 \%)$ had an education level of at least a Higher Secondary Certificate (H.S.C.) and at most a Master's degree, which suggests at least some understanding of ESG and the importance of sustainable issues in investment decision due to the easy dissemination information in the present age. Furthermore, investors with a higher income level tended to show a greater inclination towards ESG issues, which agrees with the previous literature $[30,103]$. Moreover, investors with higher investment amount invested in stock markets that had a greater preference for ESG issues. These findings have relevance to the consideration that investors with a higher investment volume have better diversifying capacities, rather than preferring short-term gain from their investments, which has a significant impact on the ESG investment decision. Therefore, the findings of the controlled variables utilized in this study can contribute to the literature as part of a cultural aspect, by profiling the investors from an emerging country like Bangladesh or countries with similar cultural environs where there are pivotal prospects of ESG investments.

\section{Conclusions}

ESG investment is becoming a wide-spread phenomenon around the world. With the aid of the questionnaire survey administered among the individual investors of the Dhaka Stock Exchange Limited (DSE) and Chittagong Stock Exchange Limited (CSE), and the carrying out of an initial interview, this study aimed to examine the ESG preferences and socio-demographic characteristics of investors in Bangladesh. The study's findings can help recognize the demand for ESG issues and will ultimately motivate companies to improve their business conduct in ESG-friendly ways. Stock market regulators will be able to use investor preferences when framing the rules and regulations in this area. The adoption and implementation of ESG rules and regulations will eventually improve the overall ESG practices of the nation, and will consequently help to preserve ecological and social balance. The investors will be ensured a sustainable investment return together with accountability towards the environment, society, and economic balance, which can pave the way towards sustainable development. Moreover, companies' virtuous practices can help in generating a 'Pareto improvement' for the whole economy [104]. Although this study ascertained the preference of certain individual investors towards ESG issues, their primary motivation for this type of investment decision was not fully explored. Hence, this could be an interesting topic for further exploration in order to illuminate social, functional, emotional, value-based, or social change motivations. Besides, the study is conducted in Bangladesh, a Muslim majority nation. Therefore, future research is encouraged in other countries with different religious and cultural environs. 
Author Contributions: The joint efforts of three authors contributed to this work. S.S. conceived the research idea, analyzed, and interpreted the results. D.Z. provided the different research materials and N.Z. reviewed the related literature and paper as a whole. All three authors contributed to the discussion and conclusion of the research.

Acknowledgments: The authors acknowledge financial assistance from the Postgraduate Research Fund (PPP), University of Malaya, Malaysia, under the grant number PG271-2015B. The authors are thankful to Dr. Imran Shafique, Lahore, Pakistan for his invaluable guidance and remarks.

Conflicts of Interest: The authors declare no conflicts of interest.

\section{References}

1. Przychodzen, J.; Gómez-Bezares, F.; Przychodzen, W.; Larreina, M. ESG issues among fund managers-Factors and motives. Sustainability 2016, 8, 1078. [CrossRef]

2. Fin, R.F.F. Environmental, social and governance investing from an idea to getting it done. InFinance 2012, $126,42$.

3. Ortas, E.; Álvarez, I.; Garayar, A. The environmental, social, governance, and financial performance effects on companies that adopt the united nations global compact. Sustainability 2015, 7, 1932-1956. [CrossRef]

4. Nevado-Peña, D.; López-Ruiz, V.-R.; Alfaro-Navarro, J.-L. The effects of environmental and social dimensions of sustainability in response to the economic crisis of European cities. Sustainability 2015, 7, 8255-8269. [CrossRef]

5. Waas, T.; Hugé, J.; Block, T.; Wright, T.; Benitez-Capistros, F.; Verbruggen, A. Sustainability assessment and indicators: Tools in a decision-making strategy for sustainable development. Sustainability 2014, 6, 5512-5534. [CrossRef]

6. Kopnina, H. The victims of unsustainability: A challenge to sustainable development goals. Int. J. Sustain. Dev. World Ecol. 2016, 23, 113-121. [CrossRef]

7. Hansmann, R.; Mieg, H.A.; Frischknecht, P. Principal sustainability components: Empirical analysis of synergies between the three pillars of sustainability. Int. J. Sustain. Dev. World Ecol. 2012, 19, 451-459. [CrossRef]

8. GSIA. The 2016 Global Sustainable Investment Review; Global Sustainable Investment Alliance (GSIA): Washington, DC, USA, 2016.

9. Stevens, C. Scales of integration for sustainable development governance. Int. J. Sustain. Dev. World Ecol. 2018, 25, 1-8. [CrossRef]

10. Carolina Rezende de Carvalho Ferreira, M.; Amorim Sobreiro, V.; Kimura, H.; Luiz de Moraes Barboza, F. A systematic review of literature about finance and sustainability. J. Sustain. Financ. Invest. 2016, 6, 112-147.

11. Jun, H.N. Investing well by investing for good? Exploring the motivations of socially responsible investors. Asian Int. Stud. Rev. 2013, 14, 29-56.

12. Ferrero-Ferrero, I.; Fernández-Izquierdo, M.Á.; Muñoz-Torres, M.J. The effect of environmental, social and governance consistency on economic results. Sustainability 2016, 8, 1005. [CrossRef]

13. Graafland, J.; Smid, H. Competition, time horizon and corporate social performance. In CentER Discussion Paper Series No. 2013-060; Economics: Tilburg, The Netherlands, 2013.

14. Caplan, L.; Griswold, J.S.; Jarvis, W.F. From SRI to ESG: The Changing World of Responsible Investing. Available online: https:/ / files.eric.ed.gov / fulltext/ED559300.pdf (accessed on 8 February 2018).

15. Independent Online Desk. Bangladesh Ranks 34 in Inclusive Development Index. Available online: http: / / www.theindependentbd.com/post/134021 (accessed on 9 February 2018).

16. World Bank. Available online: http://www.worldbank.org/en/country/bangladesh (accessed on 19 January 2017).

17. Islam, A. Bangladesh going to be the 23rd Largest Economy. Prothom Alo, 4 November 2015; 13.

18. Chowdhury, S.A. Foreign Funds in Stocks Hit Record TK 426cr. Available online: http:/ / www.thedailystar. net/foreign-funds-in-stocks-hit-record-tk-426cr-44236 (accessed on 13 December 2015).

19. Barman, B. Foreign fund in DSE jumps 792pc in 11 months. The Financial Express, 5 December 2016.

20. Tahera, K.T. Share market in Bangladesh: Its impulsive attitude towards investors and reasons behind these spontaneous changes. Int. J. Soc. Sci. Hum. Res. 2014, 2, 284-290.

21. Sabet, D.; Ishtiaque, A.S. Understanding the Hallmark-Sonali Bank Loan Scandal. Available online: http: / / ces.ulab.edu.bd/wp-content/uploads/sites/18/2015/07/Hallmark_Sonali_Jan_13sm.pdf (accessed on 1 June 2015). 
22. Butler, S. Bangladeshi Factory Deaths Spark Action among High Street Clothing Chains. Available online: http:/ / www.theguardian.com/world/2013/jun/23/rana-plaza-factory-disaster-bangladesh-primark (accessed on 23 June 2015).

23. Banarjee, S. The Fire Tragedy of Tazreen Garments; Bangladesh Institute of Labour Studies-BILS: Dhaka, Bangladesh, 2012; pp. 1-21.

24. EPI. Environmental Performance Index 2016. Available online: https://issuu.com/2016yaleepi/docs/ epi2016_final (accessed on 31 January 2017).

25. Sreekumar Nair, A.; Ladha, R. Determinants of non-economic investment goals among Indian investors. Corp. Gov. 2014, 14, 714-727. [CrossRef]

26. Dorfleitner, G.; Utz, S. Profiling german-speaking socially responsible investors. Qual. Res. Financ. Mark. 2014, 6, 118-156. [CrossRef]

27. Viviers, S.; Kruger, J.; Venter, D.J. The relative importance of ethics, environmental, social and governance criteria. Afr. J. Bus. Ethics 2014, 6. [CrossRef]

28. Berry, R.H.; Yeung, F. Are investors willing to sacrifice cash for morality? J. Bus. Ethics 2013, 117, 477-492. [CrossRef]

29. Borgers, A.C.; Pownall, R.A. Attitudes towards socially and environmentally responsible investment. J. Behav. Exp. Financ. 2014, 1, 27-44. [CrossRef]

30. Hood, M.; Nofsinger, J.R.; Varma, A. Conservation, discrimination, and salvation: Investors' social concerns in the stock market. J. Financ. Serv. Res. 2014, 45, 5-37. [CrossRef]

31. Peifer, J.L. Fund loyalty among socially responsible investors: The importance of the economic and ethical domains. J. Bus. Ethics 2014, 121, 635-649. [CrossRef]

32. Miralles-Quirós, M.M.; Miralles-Quirós, J.L.; Valente Gonçalves, L.M. The value relevance of environmental, social, and governance performance: The Brazilian case. Sustainability 2018, 10, 574. [CrossRef]

33. Diouf, D.; Hebb, T. Exploring factors that influence social retail investors' decisions: Evidence from Desjardins fund. J. Bus. Ethics 2016, 134, 45-67. [CrossRef]

34. Martí-Ballester, C.P. Investor reactions to socially responsible investment. Manag. Decis. 2015, 53, 571-604. [CrossRef]

35. Barkema, H.G.; Chen, X.-P.; George, G.; Luo, Y.; Tsui, A.S. West meets east: New concepts and theories. Acad. Manag. J. 2015, 58, 460-479. [CrossRef]

36. Geetha, S.; Vimala, K. Perception of household individual investors towards selected financial investment avenues (with reference to investors in Chennai city). Procedia Econ. Financ. 2014, 11, 360-374. [CrossRef]

37. UNGC. United Nations Global Compact. 2004. Available online: www.unglobalcompact.org/docs/issues_ doc/Financial_markets/who_cares_who_wins.pdf (accessed on 21 May 2015).

38. TRCRI. Thomson Reuters Corporate Responsibility Index. 2013. Available online: http: / / archive.annual-report.thomsonreuters.com/cr2013/downloads/thomson-reuters-2013-corporateresponsibility-report.pdf (accessed on 26 May 2015).

39. Jagongo, A.; Mutswenje, V.S. A survey of the factors influencing investment decisions: The Case of Individual Investors at the NSE. Int. J. Humanit. Soc. Sci. 2014, 4, 92-102.

40. Bikas, E.; Jurevičienè, D.; Dubinskas, P.; Novickytė, L. Behavioural finance: The emergence and development trends. Procedia Soc. Behav. Sci. 2013, 82, 870-876. [CrossRef]

41. Cohen, G.; Kudryavtsev, A. Investor rationality and financial decisions. J. Behav. Financ. 2012, 13, 11-16. [CrossRef]

42. Von Wallis, M.; Klein, C. Ethical requirement and financial interest: A literature review on socially responsible investing. Bus. Res. 2015, 8, 61-98. [CrossRef]

43. UNPRI. United Nations Principles of Responsible Investments. Available online: https://www.unpri.org/ (accessed on 15 July 2015).

44. Zhu, D. Research from global sustainable development goals (SDGs) to sustainability science based on the object-subject-process framework. Chin. J. Popul. Resour. Environ. 2017, 15, 8-20. [CrossRef]

45. Berry, T.C.; Junkus, J.C. Socially responsible investing: An investor perspective. J. Bus. Ethics 2013, 112, 707-720. [CrossRef]

46. Crifo, P.; Forget, V.D.; Teyssier, S. The price of environmental, social and governance practice disclosure: An experiment with professional private equity investors. J. Corp. Financ. 2015, 30, 168-194. [CrossRef] 
47. Belal, A.R.; Cooper, S.M.; Khan, N.A. Corporate environmental responsibility and accountability: What chance in vulnerable Bangladesh? Crit. Perspect. Account. 2015, 33, 44-58. [CrossRef]

48. Zwaan, L.; Brimble, M.; Stewart, J. Member perceptions of ESG investing through superannuation. Sustain. Account. Manag. Policy J. 2015, 6, 79-102. [CrossRef]

49. Rakotomavo, M.T. Preferences of retail investors and institutions for corporate social performance. J. Sustain. Financ. Invest. 2011, 1, 93-102.

50. Pérez-Gladish, B.; Benson, K.; Faff, R. Profiling socially responsible investors: Australian evidence. Aust. J. Manag. 2012, 37, 189-209. [CrossRef]

51. Busch, T.; Bauer, R.; Orlitzky, M. Sustainable development and financial markets: Old paths and new avenues. Bus. Soc. 2016, 55, 303-329. [CrossRef]

52. Browning, M.; Crossley, T.F. The life-cycle model of consumption and saving. J. Econ. Perspect. 2001, 15, 3-22. [CrossRef]

53. De Giorgi, E.G. Loss aversion with multiple investment goals. Math. Financ. Econ. 2011, 5, 203-227. [CrossRef]

54. Esfandyar, S.; Rahnamay Roodposhti, F.; Hashem, N.; Reza, V.-H. The objectives, strategies and characteristics of individual investors in the Tehran stock exchange. Indones. Cap. Mark. Rev. 2017, 9, 11-26.

55. Lokanan, M.E. The demographic profile of victims of investment fraud: A Canadian perspective. J. Financ. Crime 2014, 21, 226-242. [CrossRef]

56. Dočkalová, M.P.; Kocmanová, A. Comparison of sustainable environmental, social, and corporate governance value added models for investors decision making. Sustainability 2018, 10, 649. [CrossRef]

57. Alshehhi, A.; Nobanee, H.; Khare, N. The impact of sustainability practices on corporate financial performance: Literature trends and future research potential. Sustainability 2018, 10, 494. [CrossRef]

58. Jansson, M.; Biel, A.; Andersson, M.; Gärling, T. Investment style and perceived drivers of adoption of socially responsible investment among Swedish institutional investors. J. Investig. 2011, 20, 118-123.

59. Veld-Merkoulova, Y.V. Investment horizon and portfolio choice of private investors. Int. Rev. Financ. Anal. 2011, 20, 68-75. [CrossRef]

60. Fisher, K.L.; Statman, M. A behavioral framework for time diversification. Financ. Anal. J. 1999, 55, 88-97. [CrossRef]

61. Busch, T.; Hoffmann, V.H. How hot is your bottom line? Linking carbon and financial performance. Bus. Soc. 2011, 50, 233-265. [CrossRef]

62. Schreck, P. Reviewing the business case for corporate social responsibility: New evidence and analysis. J. Bus. Ethics 2011, 103, 167. [CrossRef]

63. Ajzen, I. From intentions to actions: A theory of planned behavior. In Action Control; Springer: Berlin/Heidelberg, Germany, 1985; pp. 11-39.

64. Fang, W.-T.; Ng, E.; Wang, C.-M.; Hsu, M.-L. Normative beliefs, attitudes, and social norms: People reduce waste as an index of social relationships when spending leisure time. Sustainability 2017, 9, 1696. [CrossRef]

65. Yang, K.; Jolly, L.D. The effects of consumer perceived value and subjective norm on mobile data service adoption between American and Korean consumers. J. Retail. Consum. Serv. 2009, 16, 502-508. [CrossRef]

66. Ajzen, I. The theory of planned behavior. Organ. Behav. Hum. Decis. Process. 1991, 50, 179-211. [CrossRef]

67. Fishbein, M.; Ajzen, I. Predicting and Changing Behavior: The Reasoned Action Approach; Taylor \& Francis: New York, NY, USA, 2011.

68. Alleyne, P.; Broome, T. Using the theory of planned behaviour and risk propensity to measure investment intentions among future investors. J. East. Caribb. Stud. 2011, 36, 1-20.

69. East, R. Investment decisions and the theory of planned behaviour. J. Econ. Psychol. 1993, 14, 337-375. [CrossRef]

70. Gopi, M.; Ramayah, T. Applicability of theory of planned behavior in predicting intention to trade online: Some evidence from a developing country. Int. J. Emerg. Mark. 2007, 2, 348-360. [CrossRef]

71. Warsame, M.H.; Ireri, E.M. Does the theory of planned behaviour (TPB) matter in Sukuk investment decisions? J. Behav. Exp. Financ. 2016, 12, 93-100. [CrossRef]

72. Locke, E.; Latham, G. Goal-setting theory. Organ. Behav. 1994, 1, 159-183.

73. Statman, M. Behavioral finance: Finance with normal people. Borsa Istanb. Rev. 2014, 14, 65-73. [CrossRef]

74. Abramov, A.; Radygin, A.; Chernova, M. Long-term portfolio investments: New insight into return and risk. Russ. J. Econ. 2015, 1, 273-293. [CrossRef]

75. Barberis, N. Investing for the long run when returns are predictable. J. Financ. 2000, 55, 225-264. [CrossRef]

76. Gollier, C.; Zeckhauser, R.J. Horizon length and portfolio risk. J. Risk Uncertain. 2002, 24, 195-212. [CrossRef] 
77. Dow, J.P. Age, investing horizon and asset allocation. J. Econ. Financ. 2009, 33, 422. [CrossRef]

78. Sørensen, O.B.; Pfeifer, S. Climate change issues in fund investment practices. Int. Soc. Secur. Rev. 2011, 64, 57-71. [CrossRef]

79. Ivankova, N.V.; Creswell, J.W.; Stick, S.L. Using mixed-methods sequential explanatory design: From theory to practice. Field Methods 2006, 18, 3-20. [CrossRef]

80. Lukka, K. The roles and effects of paradigms in accounting research. Manag. Account. Res. 2010, 21, 110-115. [CrossRef]

81. Krejcie, R.V.; Morgan, D.W. Determining sample size for research activities. Educ. Psychol. Meas. 1970, 30, 607-610. [CrossRef]

82. Salant, P.; Dillman, I.; Don, A. How to Conduct Your Own Survey; John Wiley \& Sons Inc.: New York, NY, USA, 1994.

83. Kock, N. A note on how to conduct a factor-based PLS-SEM analysis. Int. J. E-Collab. 2015, 11, 1-9. [CrossRef]

84. Kock, N. Warp PLS User Manual: Version 6.0; ScriptWarp Systems: Laredo, TX, USA, 2017.

85. Katz, D. The functional approach to the study of attitudes. Public Opin. Q. 1960, 24, 163-204. [CrossRef]

86. Cheah, E.T.; Jamali, D.; Johnson, J.E.; Sung, M.C. Drivers of corporate social responsibility attitudes: The demography of socially responsible investors. Br. J. Manag. 2011, 22, 305-323. [CrossRef]

87. Jansson, M.; Biel, A. Motives to engage in sustainable investment: A comparison between institutional and private investors. Sustain. Dev. 2011, 19, 135-142. [CrossRef]

88. Shultz, K.S.; Whitney, D.J.; Zickar, M.J. Measurement Theory in Action: Case Studies and Exercises; Routledge: London, UK, 2013.

89. Boccaletti, S.; Moro, D. Consumer willingness-to-pay for gm food products in Italy. AgBioForum 2000, 3, 259-267.

90. Nilsson, J. Investment with a conscience: Examining the impact of pro-social attitudes and perceived financial performance on socially responsible investment behavior. J. Bus. Ethics 2008, 83, 307-325. [CrossRef]

91. Hair, J.F., Jr.; Hult, G.T.M.; Ringle, C.; Sarstedt, M. A Primer on Partial Least Squares Structural Equation Modeling (Pls-Sem), 2nd ed.; Sage Publications: Los Angles, CA, USA, 2016.

92. Nunnally, J.C.; Bernstein, I.H. Psychological Theory; McGraw-Hill: New York, NY, USA, 1994.

93. Fornell, C.; Larcker, D.F. Evaluating structural equation models with unobservable variables and measurement error. J. Mark. Res. 1981, 18, 39-50. [CrossRef]

94. Hair, J.F.; Black, W.C.; Babin, B.J.; Anderson, R.E. Multivariate Data Analysis; Prentice Hall: Upper Saddle River, NJ, USA, 2009.

95. Hair, J.F.; Ringle, C.M.; Sarstedt, M. PLS-SEM: Indeed a silver bullet. J. Mark. Theory Pract. 2011, 19, $139-152$. [CrossRef]

96. Lindell, M.K.; Whitney, D.J. Accounting for common method variance in cross-sectional research designs. J. Appl. Psychol. 2001, 86, 114-121. [CrossRef] [PubMed]

97. Schreiber, J.B.; Nora, A.; Stage, F.K.; Barlow, E.A.; King, J. Reporting structural equation modeling and confirmatory factor analysis results: A review. J. Educ. Res. 2006, 99, 323-338. [CrossRef]

98. Kock, N.; Gaskins, L. The mediating role of voice and accountability in the relationship between internet diffusion and government corruption in Latin America and Sub-Saharan Africa. Inf. Technol. Dev. 2014, 20, 23-43. [CrossRef]

99. Cohen, J. Statistical Power Analysis for the Behavioral Sciences; Lawrence Erlbaum Associates: Hillsdale, NJ, USA, 1988.

100. Kline, R.B. Principles and Practice of Structural Equation Modeling, 3rd ed.; Guilford Publications: New York, NY, USA, 2010.

101. Wetzels, M.; Odekerken-Schröder, G.; Van Oppen, C. Using pls path modeling for assessing hierarchical construct models: Guidelines and empirical illustration. Manag. Inf. Syst. Q. 2009, 33, 177-195. [CrossRef]

102. Guzavicius, A.; Vilkè, R.; Barkauskas, V. Behavioural finance: Corporate social responsibility approach. Procedia Soc. Behav. Sci. 2014, 156, 518-523. [CrossRef] 
103. Escrig-Olmedo, E.; Muñoz-Torres, M.J.; Fernández-Izquierdo, M.Á. Sustainable development and the financial system: Society's perceptions about socially responsible investing. Bus. Strategy Environ. 2013, 22, 410-428. [CrossRef]

104. Renneboog, L.; Ter Horst, J.; Zhang, C. Socially responsible investments: Institutional aspects, performance, and investor behavior. J. Bank. Financ. 2008, 32, 1723-1742. [CrossRef] 